\title{
Oil Pulling for Better Oral Health-Myth or Reality?
}

\author{
Vinita A Boloor* and Rajesh R Hosadurga \\ Department of Periodontology, Yenepoya Dental College, India
}

Submission: February 10, 2017; Published: August 13, 2018

*Corresponding author: Vinita Boloor, Associate Professor, Department of Periodontology, Yenepoya Dental College, Mangalore, India, Tel: +919845114652; Email: drvinitaboloor@gmail.com

Summary

Oil pulling or oil swishing, in alternative medicine, has been used to prevent decay, oral malodor, bleeding gums, and dryness of throat, and cracked lips and for strengthening teeth, gums, and jaws, for which various natural oils like refined sunflower oil, sesame oil, olive oil, coconut oil and liquids like milk and water, gooseberry and mango extracts have been used.

Abstract

In this era of holistic approach traditional methods of treatment are gaining importance. Traditional medicine lays emphasis on natural product usage and has few side effects. Oil pulling or oil swishing, in alternative medicine, has been used to prevent decay, oral malodor, bleeding gums, and dryness of throat, and cracked lips and for strengthening teeth, gums, and jaws. It is a simple rejuvenating treatment which when done routinely, enhances the senses, maintains clarity, brings a feeling of freshness and invigorates the mind. Various natural oils like refined sunflower oil, sesame oil, olive oil, coconut oil and liquids like milk and water, gooseberry and mango extracts have been used for oil pulling.

Keywords: Traditional medicine; Oil pulling; Natural oils; Sunflower oil; Coconut oil; Sesame oil; Milk; Water

\section{Introduction}

In this era of holistic approach traditional methods of treatment are gaining importance. Traditional medicine lays emphasis on natural product usage and has few side effects [1]. Oil pulling or oil swishing, in alternative medicine, has been used to prevent decay, oral malodor, bleeding gums, and dryness of throat, and cracked lips and for strengthening teeth, gums, and jaws [2-5]. There are two types Gandusha and Kavalagraha. Gandusha involves filling the oral cavity completely with liquid medicine held for about three to five minutes and then released. In Kavalagraha, a comfortable amount of fluid is retained within the mouth for about three minutes and then gargled. It is a simple rejuvenating treatment which when done routinely, enhances the senses, maintains clarity, brings a feeling of freshness and invigorates the mind. Various natural oils like refined sunflower oil, sesame oil, olive oil, coconut oil and liquids like milk and water, gooseberry and mango extracts have been used for oil pulling [6].

\section{Procedure of oil pulling}

It is better to perform it during early morning hours, on an empty stomach slowly in sitting position with chin up. A tablespoon of oil is taken in the mouth, sipped, sucked and pulled between the teeth for ten to fifteen minutes. The viscous oil turns thin and milky white. It is claimed that the swishing activates enzymes and draws toxins out of the blood. The oil should not be swallowed as it contains bacteria and toxins. Oil pulling therapy should be followed by tooth brushing and rinsing of the mouth with warm water or salt water. The procedure can be done for a maximum of three times in a day in case of acute diseases. It is contraindicated for children below the age of five years due to danger of aspiration and swallowing. It can be practiced even during pregnancy and menstruation. Unlike chlorhexidine no time gap is advised after oil pulling and rinsing [7, 8].

\section{Mechanism of Action}

The exact mechanism of oil pulling still remains unclear. It is assumed that swishing the oil in the mouth activates enzymes and pulls the toxins out of the blood [1,9]. Another proposed mechanism states that the viscosity of the oil may prevent bacterial adhesion and coaggregation. Moreover, recently an invitro study proposed that the effects of oil-pulling therapy showed clear indications of possible saponification and emulsification process which enhances its mechanical cleansing action [6]. Sesame oil is a vegetable fat which when reacted with salivary alkalis like bicarbonates causes saponification by acting as an emulsifying agent. This emulsification increases the surface area of oil and promotes better cleansing action [6].

\section{Effects}

Oil pulling, a biological healing method was found to cure a variety of symptoms without side effects. The simplicity of 
this healing system is that oil has a stimulating effect on body's alimentary system. It was found to possibly heal individual cells, cell conglomerates such as lymph nodes and more complex tissues like internal organs simultaneously. This occurs because beneficial microflora throughout the body is provided with a healthy continuum that enables the usual pattern of human health to lean towards wellness than illness $[10,11]$.

\section{Systemic Diseases Treated}

In total, oil pulling heals the whole body in perpetuity. It cures migraine, headaches, bronchitis, arterial thrombosis, chronic blood diseases like leukemia, arthritis, neurophysiologic paralysis, eczema, gastroenteritis, peritonitis, cardiac and renal diseases, meningitis and women's hormonal disorders [10-15].

\section{Discussion}

Ayurveda, a part of alternative medicine is gaining back its importance in various aspects of health, as it uses all natural products. Oil pulling is one such age old process which has innumerable systemic and dental health benefits. It has become a mystic cure for many systemic diseases like diabetes, migraine etc.

Several studies done on the efficacy of oil pulling in improving oral health including anti-caries effect, anti-halitosis effect using various oils like sesame oil, sunflower oil and coconut oil have shown that oil pulling is equally effective to chlorhexidine mouth rinses (Table 1). Hence the evidence suggests that oil pulling can be used as a useful adjunct in improving and maintaining oral health

Table 1: Showing studies conducted on the efficacy of oil pulling.

\begin{tabular}{|c|c|c|c|c|c|}
\hline Sl. No & Oil used & Authors & Objectives of the Study & Results & Conclusion \\
\hline 1 & Sesame oil & Asokan S, et al. [12] & $\begin{array}{l}\text { Effect of oil pulling with sesame oil on } \\
\text { the count of Streptococcus mutans in } \\
\text { plaque and saliva of children, using } \\
\text { the Dentocult SM Strip mutans test, } \\
\text { and to compare its efficacy with that of } \\
\text { chlorhexidine mouthwash }\end{array}$ & $\begin{array}{l}\text { Significant reduction in } \\
\text { the count of Streptococcus } \\
\text { mutans in plaque }\end{array}$ & $\begin{array}{l}\text { Effective \& preventive } \\
\text { adjunct in oral health } \\
\text { maintenance. }\end{array}$ \\
\hline 2 & Sesame oil & Asokan S, et al. [12] & $\begin{array}{l}\text { Evaluate the effect of oil pulling } \\
\text { with sesame oil on halitosis and } \\
\text { the microorganisms that could be } \\
\text { responsible for it and to compare its } \\
\text { efficacy with chlorhexidine mouthwash. }\end{array}$ & $\begin{array}{c}\text { Equally effective like } \\
\text { chlorhexidine on halitosis } \\
\text { and organisms, associated } \\
\text { with halitosis. }\end{array}$ & $\begin{array}{l}\text { Useful adjunct in oral } \\
\text { health maintenance. }\end{array}$ \\
\hline 3 & Sesame oil & $\begin{array}{l}\text { T Durai Anand, et } \\
\text { al. [13] }\end{array}$ & $\begin{array}{l}\text { Effect of oil-pulling on the reduction } \\
\text { of total count of bacteria. The in-vitro } \\
\text { antibacterial activity of sesame oil } \\
\text { against dental caries causing bacteria } \\
\text { was determined. }\end{array}$ & $\begin{array}{l}\text { Reduction in the total count } \\
\text { of bacteria. Streptococcus } \\
\text { mutans and Lactobacillus } \\
\text { acidophilus were moderately } \\
\text { sensitive. }\end{array}$ & $\begin{array}{l}\text { The process of oil- } \\
\text { pulling had reduced } \\
\text { the susceptibility of a } \\
\text { host to dental caries }\end{array}$ \\
\hline 4 & Sunflower oil & Amith, et al. [14] & $\begin{array}{l}\text { Assessed the effect of sunflower oil } \\
\text { pulling on Plaque and Gingivitis and } \\
\text { monitored its safety on oral soft and } \\
\text { hard tissues. }\end{array}$ & $\begin{array}{l}\text { No adverse reactions to any } \\
\text { hard and soft tissues of the } \\
\text { oral cavity. }\end{array}$ & $\begin{array}{l}\text { Low levels of plaque } \\
\text { and gingivitis at } 45 \\
\text { days }\end{array}$ \\
\hline 5 & Coconut oil & $\begin{array}{c}\text { Intahphuak S, et al. } \\
{[15]}\end{array}$ & $\begin{array}{l}\text { The anti-inflammatory, analgesic, and } \\
\text { antipyretic effects of Virgin coconut oil } \\
\text { (VCO) were assessed. }\end{array}$ & $\begin{array}{l}\text { In acute inflammatory } \\
\text { models, VCO showed } \\
\text { moderate anti-inflammatory } \\
\text { effects. Inhibitory effect } \\
\text { on chronic inflammation. } \\
\text { Moderate analgesic effect } \\
\text { and antipyretic effect in } \\
\text { yeast-induced hyperthermia }\end{array}$ & $\begin{array}{l}\text { Possess anti- } \\
\text { inflammatory, } \\
\text { analgesic, and } \\
\text { antipyretic properties }\end{array}$ \\
\hline
\end{tabular}

\section{Conclusion}

Few short term studies have demonstrated the beneficial effects of oil pulling on plaque, gingivitis and dental caries prevalence suggesting that it be used as an oral hygiene maintenance aid. Further research with long term studies is in need to explore the other effects of oil pulling therapy on overall health. Scientific validations of the ayurvedic dental health practices could justify their incorporation into modern dental practice. Overall, as is true for many folk remedies, oil pulling therapy has insufficient peer-reviewed scientific studies to support its use for oral conditions.

\section{Acknowledgements}

The authors gratefully acknowledge Dr.B.H.Sripathi Rao, Dr. Shashikanth Hegde, Dr. Rajesh K S. Dr Arun Kumar M S , staff and Department of Periodontology, Yenepoya University.

\section{References}

1. Namiki M (1995) The chemistry and physiological functions of sesame. Food Rev Int 11: 281-329.

2. http://www.maharishi-european-sidhaland.org/

3. http://www.oilpulling.com 
4. http://www.indiaids.org/alt_ther/ayurveda.asp\#a4.com

5. http://www.ayurvediccure/mouthcare.html

6. Asokan S (2008) Oil pulling therapy. Indian J Dent Res 19(2):169.

7. Dingari LC (2000) The Shalakya Tantra II.1 $1^{\text {st }}$ ed. Hyderabad: Smt D Kamala Publishers 2000: 233-57.

8. http://www.oilpulling.com/index.htm

9. http://www.healthstores/sesameoil.com

10. http://www.ayurvediccure.com/mouthcare.html.

11. Ram KS (2002) Agnivesa's Charakasamhita (Sutra Sthana). Varanasi: Chowkhamba Sanakrit Series office 1: 99-100.
12. Asokan S, Rathan J, Muthu MS, Rathna PV, Emmadi, et al. (2008) Effect of oil pulling on Streptococcus mutans count in plaque and saliva using Dentocult SM Strip mutans test: a randomized, controlled, triple-blind study. J Indian Soc Pedod Prev Dent 26(1): 12-7.

13. Durai Anand T, Pothiraj C, Gopinath RM, Kayalvizhi B (2008) Effect of oil-pulling on dental caries causing bacteria. African Journal of Microbiology Research 2: 63-66.

14. Amith HV, Anil V Ankola, Nagesh L (2007) Effect of oil pulling on plaque and gingivitis. J Oral Health Comm Dent 1(1): 12-18.

15. Intahphuak S, Khonsung P, Panthong A (2010) Anti-inflammatory, analgesic, and antipyretic activities of virgin coconut oil. Pharm Biol 48(2): 151-157.

\section{Your next submission with Juniper Publishers} will reach you the below assets
- Quality Editorial service

- Swift Peer Review

- Reprints availability

- E-prints Service

- Manuscript Podcast for convenient understanding

- Global attainment for your research

- Manuscript accessibility in different formats

( Pdf, E-pub, Full Text, Audio)

- Unceasing customer service

Track the below URL for one-step submission https://juniperpublishers.com/online-submission.php 